\title{
都市空間における遣水型水路網に関する研究*
}

\section{A Study on the Network of Landscaped Channels in Town*}

河端 邦彦**・山田圭二郎***・中村 良夫****

By Kunihiko KAWABATA** , Keijiro YAMADA ***, Yoshio NAKAMURA****

\section{1.はじめに}

(1)研究の背景と目的-遣水型水路網-

日本庭園の伝統的な技法の一つである「遣水」には, 自然の河川や疎水などから水を引き入れ庭園内の池や流 れに利用する例が数多く見られる. 著名なものとしては 京都市北区上賀茂社家町（伝統建造物群保存地区）にお

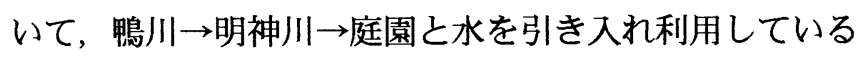
神官屋敷（社家）の庭園などがある。

このような例には自然河川から遣水に至るその過程に 段階的な水位の調節が行われており，「自然の水を次第に 人へと近づけ，楽しむ」という日本人の水に対する伝統 的な知恵が見受けられる.

本研究では, 滋賀県大津市坂本町を対象とした. 坂本 の水路は自然河川から取水された水路が複雑に分岐・合 流を繰り返し，町全体へ展開してゆくことで形成され， 数多くの庭園がこの水路より取水し, 遣水として利用し ている. 本研究では，庭園内の遣水にとどまらず，自然 河川から取水し水量の段階的調節を経て身近な空間へ引 き込む過程の全てを「水の遣水的利用」 ${ }^{1)}$ と捉え，このよ うな利用法により形成された自然河川から遣水に至る一 つの流水システムを「遣水型水路網」と呼ぶ.

本研究では, 水路網を一つのシステムとして捉え, 水 路網の持つネットワーク構造を支える重要な要素と思わ れる「分岐」と「勾配 (高低差)」という 2 つの視点から システムを分析し，明らかにする事を目的とする.

また，この水路網を支えるコミュニティについても言 及し，これにより局所的な親水空間の創造にとどまらず 都市的な広域空間に親水空間を作る上での新たな示唆が 得られるものと考える.

(2)研究対象地域とその概要

(a)歴史的背景 2) 3)

*Keywords : 景観, 親水計画

** 学生員 京都大学大学院工学研究科土木システム工学専攻

*** 正員 工修 京都大学大学院工学研究科土木システム工学専攻

**** 正員 工博 京都大学大学院工学研究科土木システム工学専攻 （テ606-8501 京都市左京区吉田本町

Tel 075-753-4788 Fax075-753-4789)
坂本の発展は 788 年の最澄による比頻山延暦寺の創建 から始まり, 平安時代中後期から盛んになった日吉参詣 を経て, 中世には延暦寺・日吉大社の門前町として, 畿 内では京都・奈良に次ぐ大都市となっていた. その後は 戦乱による衰退と繁栄が繰り返された. 明治時代に入る 頃には廃仏毀釈の影響を受け，窮地に追い込まれたりも したが，現在は歴史的な景観のある町として町並み整備 が進められている.

本研究で対象とした水路網・庭園群は里坊しよばれる 坂本独特の居住形式と一体となって存在している. 里坊

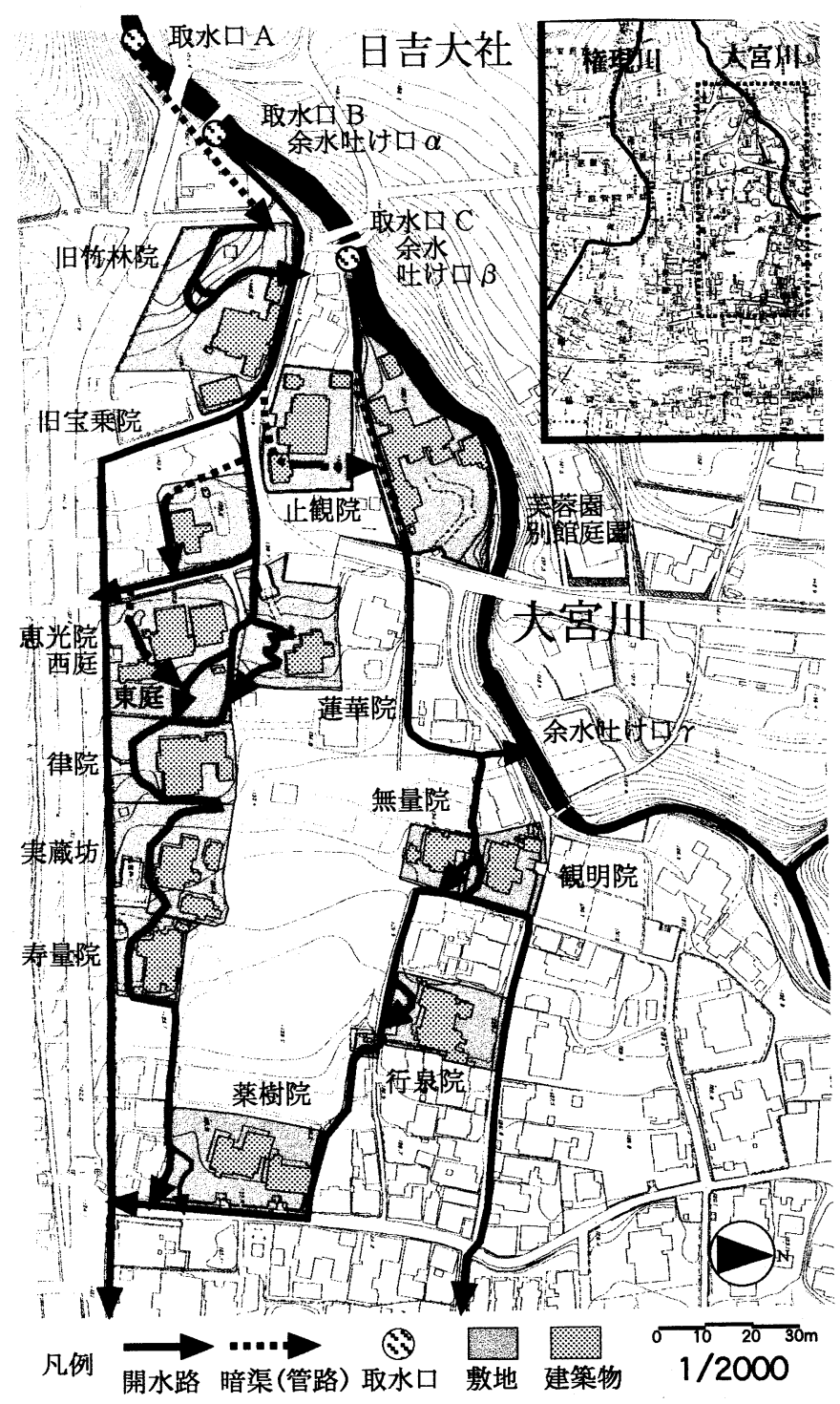

図-1 坂本水路網（大宮川沿い） 
の営みは 16 世紀末から 17 世紀初頭に始まり，比蹾山山 上の修行を隠退した僧侶らが晚年を過ごした所であり, 里坊内の庭園は彼らのもっとも身近なアメニティとして の役割があったと思わる. 坂本は水が豊富であり, 遣水 を用いた庭園が多い.この庭園群・水路網はこの里坊と いう特殊なコミュニティによって管理されており, 地域 住民参加型のまちづくりという観点からも大変興味深い.

(b) 地形的概要

坂本の町は比㩚山の山麓に位置し，比頻山から流れる 大宮川, 権現川の周囲に発達した町であり, 全体的になだ らかな斜面の上に成り立っている.

坂本の水路網は大宮川を取水源とする大宮川水系と権 現川を取水源とする権現川水系の 2 系統が存在し, これ らはそれぞれ交わる事なく，日吉大社への参道を境にし て南北に分布している. 本研究では, 水路の持つネット ワーク構造に着目し, 分岐と勾配の側面から詳細に調 査・分析を行うため, 上記 2 系統の内, 大宮川水系に対 象を絞り, 図-1 に示す里坊庭園群を対象地域とした.

\section{(3)調査の概要}

調査は, 大津市発行 (1987 年度版) 大津市現況平面図 $(1 / 500)$ に基づき, 現地踏査により水路の現況を把握した.

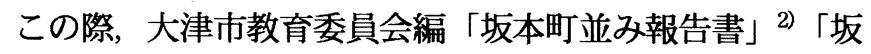
本里坊庭園調査報告書」 ${ }^{3)}$ を参考にした. 現地踏査におい ては, 各水路の勾配及び高低差をトランシットを用いた 水準測量により測定した. また各水路の平面, 断面及び 水深を計測した. また, 竹林院管理者, 寿量院・恵光 院・旧白豪院の住人の方, 近隣住人の方にヒアリングを 行い参考とした.

\section{2.水路のネットワーク構造}

坂本町内の大宮川水系の水路網は図一-1のような複雑な ネットワーク構造をしている.この構造を明膫に把握する ため, 図-2のような模式図を作成した. これによると, 大宮川水系の水路網は 3 つの取水口 $\mathrm{A}$ （河川の中に塩化 ビニル管を設置したもの)， B（河川に石を並べそれによ り水を水路に引き入れるもの), $\mathrm{C}$ (B と同型/写真-1) により取水した水の分流・合流により形成されている.

\section{(1)水量調節}

ネットワーク内の水は水路の各分岐点で水量が段階的 に調節された後, 各庭園に配水され, 全体の水量が安定に 保たれている. この具体的な構造は図-3，4 に示した取水 口 A， B 及び取水口 C から取り込んだ水路の水量調節段 階からも見てとれる. (図中の数字は水量調節の段階) こ の図に示された通り, 庭園内, 参道で利用される水のほと んどは 2 段階以上水量調節を受けている. また, 水量調節 構造の中で計 3 力所に置かれている洪水吐けはネットワー ク内の水量安定に重要な役割を果たしている.

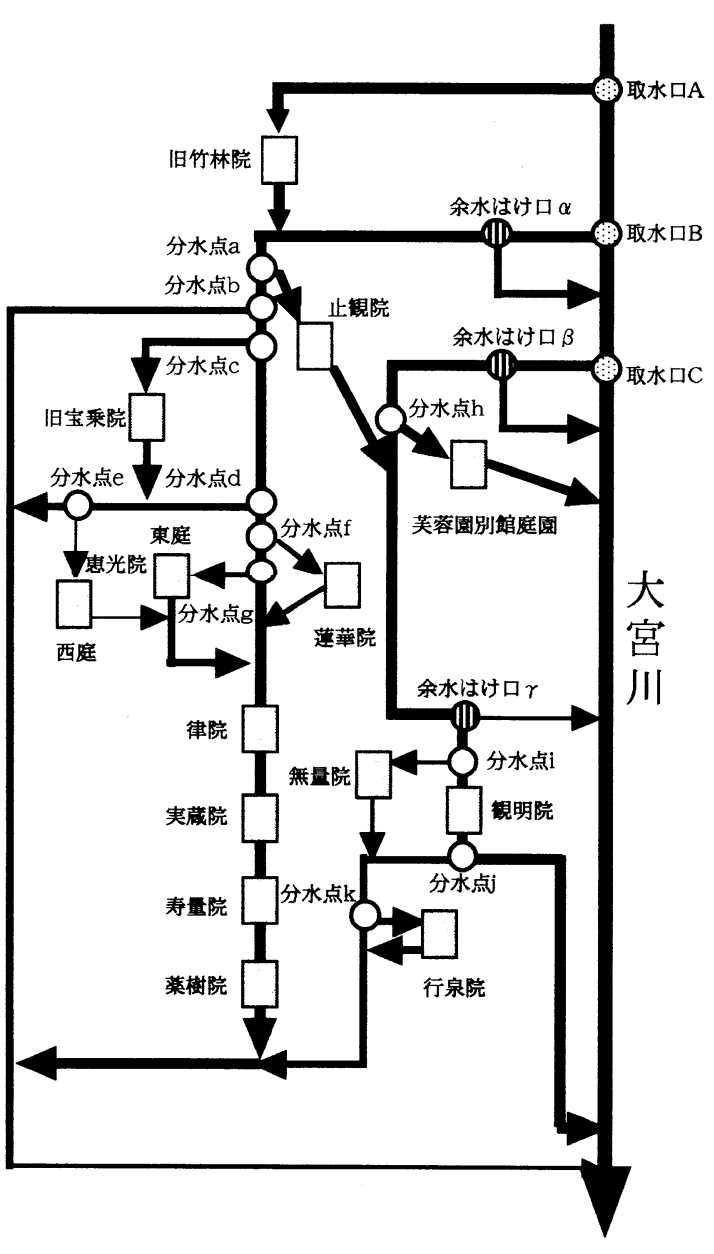

図- 2 水路模式図

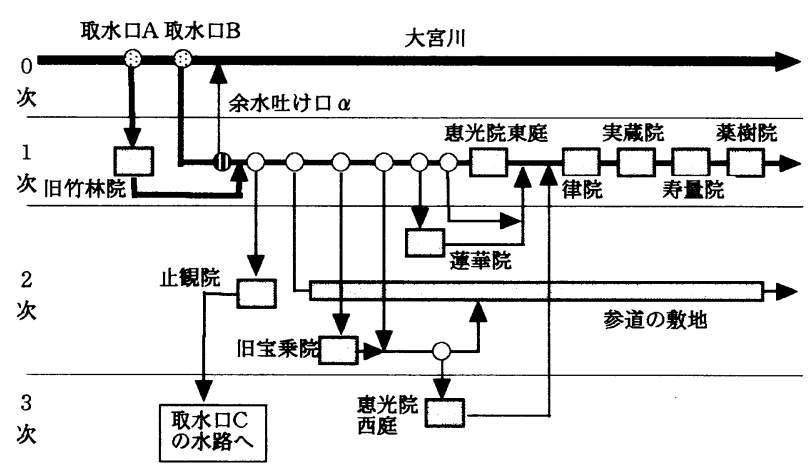

図-3 水量調節段階図（取水口 A，B）

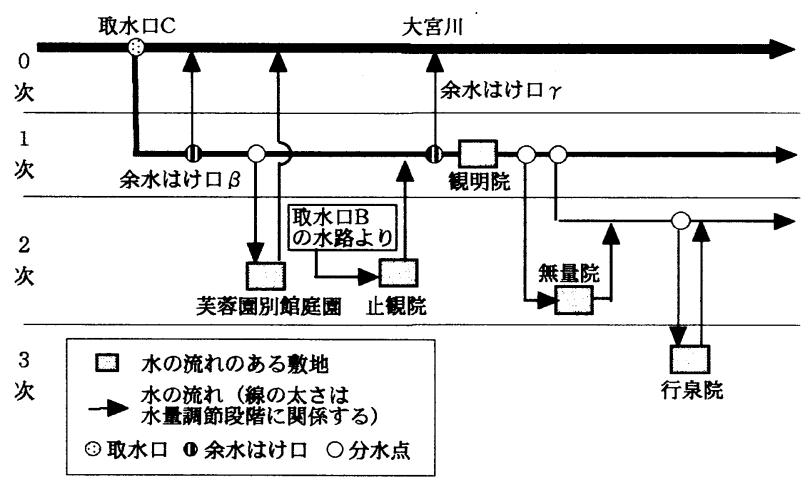

図-4 水量調節段階（取水口C） 
以上から，水路網は段階的な水量調節による階層構造を ち，水位の安定した水が敷地，庭園内に取り込まれている ことが分かった.

本章次節以降では，この階層構造を成立させる上で必要 な水量調節方法, 水路の分岐, 環流方式を分析, 整理し記 述した.

\section{(2)水量調節方法}

各分水点における水量の調節方法には, 平面型・越流 型・管路型があった. 以下に各々の特徵を示す.

・平面型……水路内平坦部に石などを並べて置き，それに より水を二手に分けるもの. この型は大きな水 量が扱える一方, 最大流量の制限が無いため, 直後，またはその系の中に余水吐け口が設置さ れる.この型は主に河川からの取水口に設けら れることが多い. (写真-1，2，図-5)

・越流型……水路内に堰, または同様の働きをするものを 設置し，その越流分を分岐させ新たな水路に流 すもの. 水量の細かい調整は可能であるが，流 量が少ない場合には難しい（写真-3，図-6）

- 管路型……水路に管路を接続し，その管内に流れ込んだ 分を新たに水路とするもの. 主に庭園への取込 口に使われる，最大流量の制限はあるが，管の つまりなど管理が難しい．(写真-4，図-7)

（3）分岐・環流形式

水量調節段階図（図-3，4）に示した「水を分岐させ， 遣水として用い，また水路へ戻す」という過程には以下の ような形式が見られた。

(1)分岐させた水を同一の水路に戻す

一番多く見られる方式で流量調節・管理が簡単である. (2)分岐させた水を異なる水路に戻す

(1)の変形で, 敷地の傾斜等の理由により，同一の水路 に戻せない場合に用いられる．特に水量調節段階が下位 の水路に排水する場合には, 流量の調節が複雑になり, 安全のため余水吐け口が設置される.（例 : 止観院)

(3)水を分岐させず連続した敷地を貫流させる

水量が少なく分岐する余裕が無い場合，または大流 量のダイナミックな流れを庭園内で作る場合に用いられ る. (例 : 律院・実蔵院等) （図-8参照） 庭園へ水を引く方法（設備）にも違いがあり，筧，ポ ンプ, サイフォンなどが見られた.

\section{(4) 複合利用}

水路の中には洗濯・食器洗いとして利用されたであろう 洗い場（写真-5）や，現在も洗い物用に屋内まで水を引 いている家屋があり，水路の複合利用が見られる.

また, 日吉大社への参道両脇を平行に流れる水路（写真 -6）は庭園と同様に複次的な水量調節がされており（図一 3), 一方では洪水時の排水機能も受け持つ興味深い例と

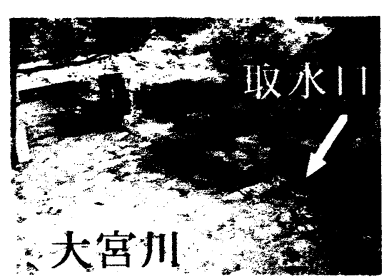

写真- 1 取水口 B

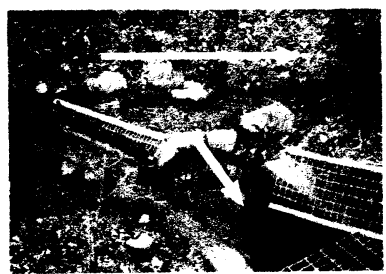

写真- 3 分水点 $f$

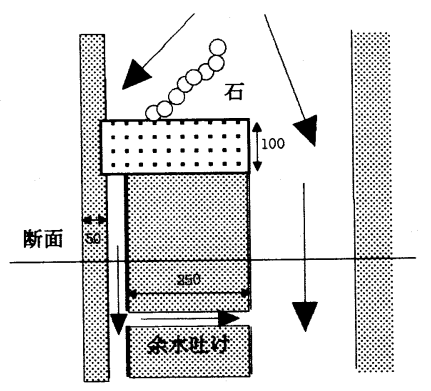

図-5 平面型 平面・断面図 (取水口 B)

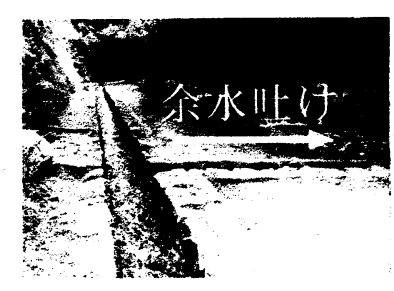

写真- 2 余水吐け口 $\alpha$

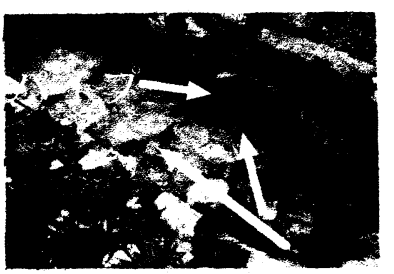

写真- 4 分水点 $d$

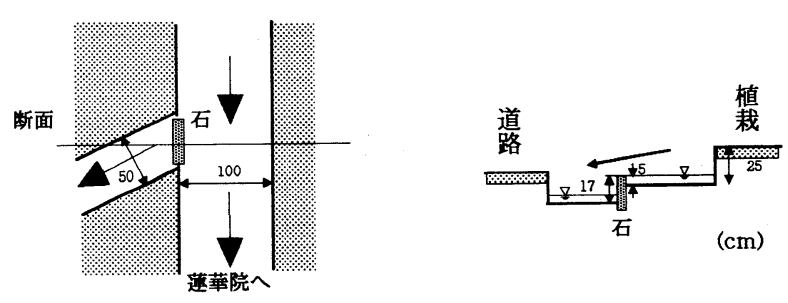

図- 6 越流型 平面・断面図 (分水点 $f$ )
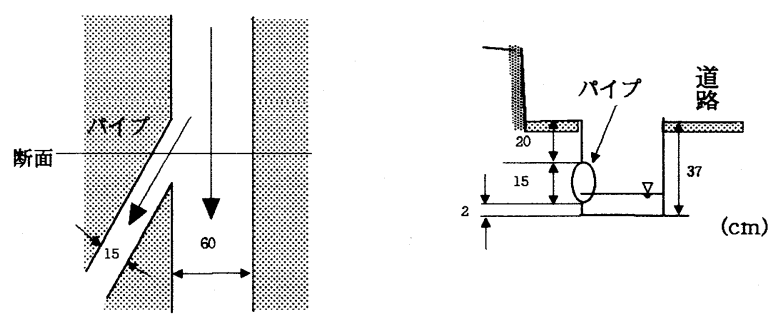

図-7 管路型 平面・断面図（分水点 $\mathrm{d}$ ）

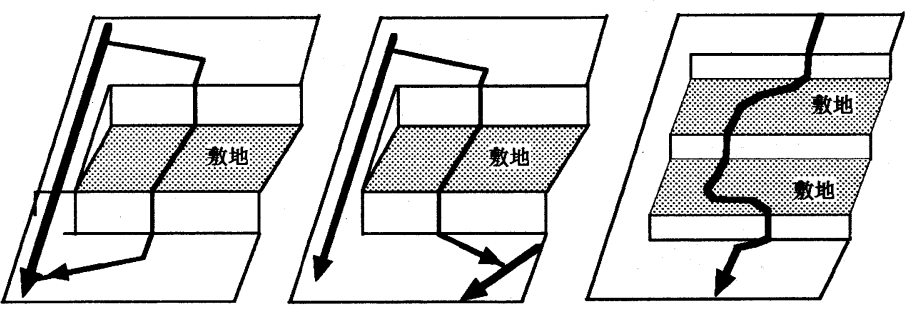

(1)

(2)

(3)

図-8 分岐 - 環流形式模式図 
言える. 坂本において，この水路は単なる水路としてでは なく, 宗教的な「㘯夫゙き等の役割を持ち, 日吉大社の神聖 な参道空間を形成する上で重要な役割を果たしている.

以上のように水路網は庭園における遣水利用の他，生活 用水や宗教的役割を担うなど，複合的に利用されている.

\section{3.地形を利用した水路椆の構成-勾眍と高低差-}

\section{(1)地形の利用}

大宮川沿いの遣水を用いた庭園の敷地を図-9に示した. 図に示した通り，町全体は緩やかな斜面(50～60/1000)で あり，この勾配を生かして水路網が形成されている.

自然河川より 8〜 10m 高い標高に位置する都市空間を流 れる水路網に自然河川から水がどのように引かれているか を図-10 に示した. 自然河川が大きな落差・急勾配 (約 400/1000)で流下するのに対し, 水路網の水は川の上流か ら取水し，自然河川に比べ緩やかな勾配(20〜30/1000)で町 内まで水が引かれている. その後は, 地形に沿い水路を作 り，自然河川から都市空間内に水を引きこんでいる.

次に水路自体に着目し, 取水口 A，B から各庭園まで流 れる水路の勾配を追跡した. その勾配は図-11 に示す通り である. 全体としてほぼ一様な勾配を保っている.

以上から，水路網は地形を生かすことで,広範囲に水を まさに網の目のように配することができている. また，こ れは同時に次に述べる高低差を利用した多彩な遣水の基盤 となっている.

\section{(2)水路網内に発生する高低差}

先に示した勾配はネットワークの一部であるが，この勾 配が絡み合い，複雑な構造のネットワークが形成されてい る.このように複雑なネットワークを利用した水の分配は, 図-9の様なさほど特徵の無い一様な地形勾配を持つ都市 空間の中に，多様な高低差を生む. これにより周囲を水路 に囲まれた敷地ではどのような効果が得られるか，旧竹林 院・律院を例に挙げて以下に説明する.

\section{（a）旧竹林院 [平面図（図-12）水路縦断図（図-13）]}

竹林院は今回対象とした里坊の中でも最も上流部にあり, 敷地の周囲の道路より一段高いところにある．建築は大正 時代に建てられた 2 棟の茶室と四阿があり，庭園は昭和初 期に整備し直されたものである.

この庭園の遣水は取水口 A からサイフォンを用いて引 き入れている. (写真-7) そのため, 周辺より高い土地 にありながら水が流れているという意外性がある. 遣水は, 大きな築山でその流入口が見えなくなっており，その背後 には八王寺山が借景として取り入れられて，水が山から流 れ出てくる様な印象を受け, また庭園が山の一部の様にも 感じられる (写真-8). 遣水は緩やかに斜面に沿って流 れており，滝組の所で視界に入る. その後は緩やかな流れ とやや急な流れの二つに別れ，水の様々な様相が楽しめる.

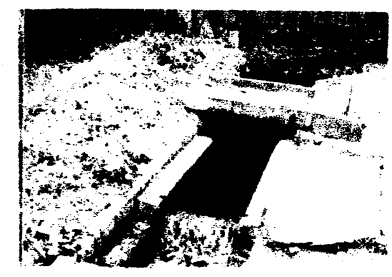

写真-5 洗い場
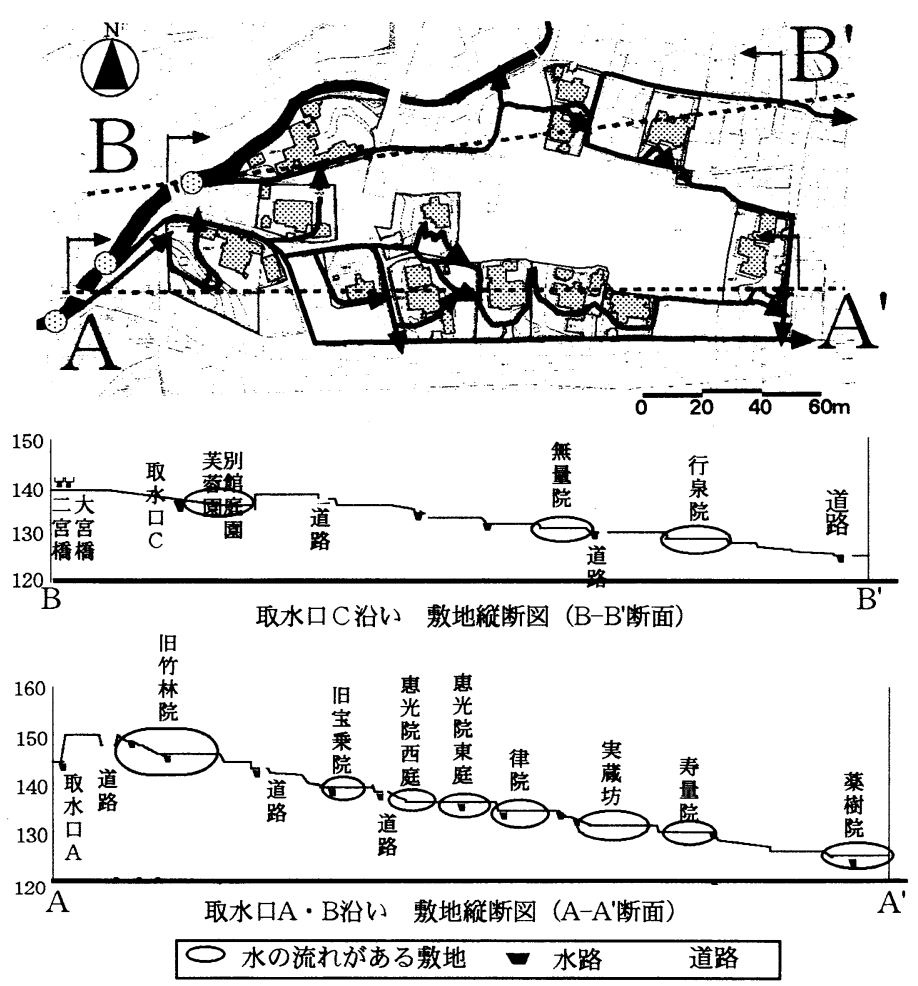

図-9＼cjkstart地形と遣水のある敷地の関係

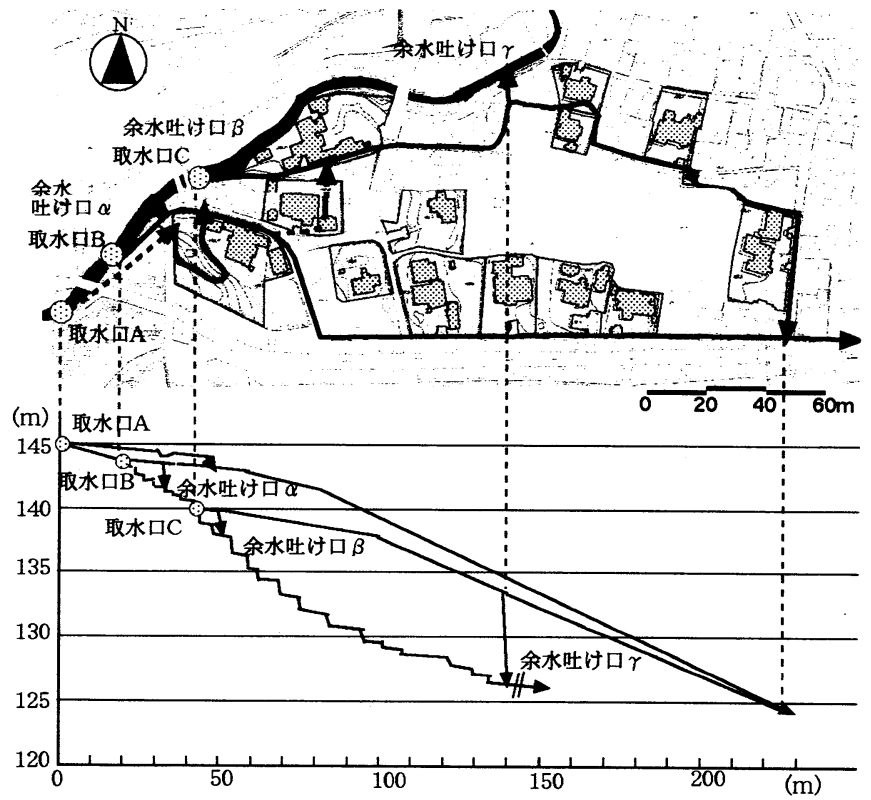

図-10 水路間の高低差

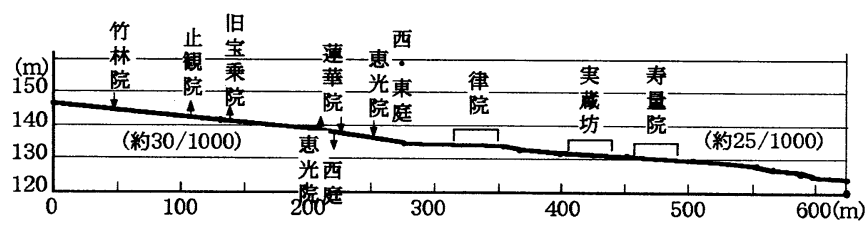

図-11 取水口 A ・ B の水路縦断図（图-9 A-A'沿い） 
（b）律院 [平面図（図-14）水路縱断図（図-15）]

庭園は正保年間に作られたものと考えられ，その後も改 修の手が入っている. 水は恵光院・蓮華院の敷地内を通つ て律院玄関に至り，壁の下をくぐり園内に流れ込んでいる. 排水は石垣の下から実蔵坊に流れている. この流れはその まま連続して寿量院・薬樹院へと流れている.

律院は旧竹林院と対照的に水の流入から流出まで全て視 界に入っている. 全体として流水の幅が広く，平たい流れ の中にも勾配が巧みに変化し，せせらぎが楽しめる. さら に，敷地に流れ込む箇所に滝口を設け，せせらぎとは異な る水音も楽しめるようにもなっている。

上記の二庭園以外の庭園に見受けられる工夫も含めて以 下にまとめた。

敷地内外で高低差の大きいところでは,

（1高低差を生かし，大きな滝をつくる.

(2)敷地間に斜面を造り，その斜面を生かし，長く緩や かな流れをつくる.

(3)(1)と(2)の併用. 斜面をつくり，長く緩やかな流れと 滝の両方を併せ持たせる.

敷地内外の高低差が小さいところでは,

(4)全体に緩やかな流れをつくる.

(5)大きな園地を造ることにより高低差を一力所にまと め, 滝・水落をつくる.

また，周囲を水路に囲まれていると，取水位置と排水位 置の位置に自由度が生まれ，庭園内の勾配，遣水線形を比 較的自由に選択できるという特徴がある．このことは坂本 の町のいたる所に水を利用する敷地が有り (図-9参照), その位置に地理的，地形的な偏りが無く，また各々の庭園 が異なるな遣水の様式で，様々な風情を持つことからも推 測される. しかし，坂本の水路網の形成過程と都市形成の 過程の関係については明らかではなく，今後それらの経緯 に関する詳細な調查，研究が望まれよう。

\section{4. 水路棢に見る自然と人の関係}

2 章で水路網は段階的な水量調節による階層構造を持つ ことを明らかにした． 3 章で水路網による地形と人の手の 入れ方の関係を明らかにした.この 2 つを総合的に考察す ると水とそれを利用する人間の関係が浮かび上がってくる. 水量を段階的に調節する過程とは水の危険性を莪減して いると考えられ，これは自然の(Wild)水から人の手の入っ た(Humanized)水へ近づけようとする意図がある.そし てこの意図の基にあるものは庭園という極めて私的な空間 で水を利用する事であるが，水路網全体を見たとき，自然 河川から遣水にいたる空間的な広がりを持つ水アメニティ システムと位置付けることができる. そして，このアメニ ティシステムをより効果的に演出する道具として地形を生 かした様々な工夫があると認識できた.

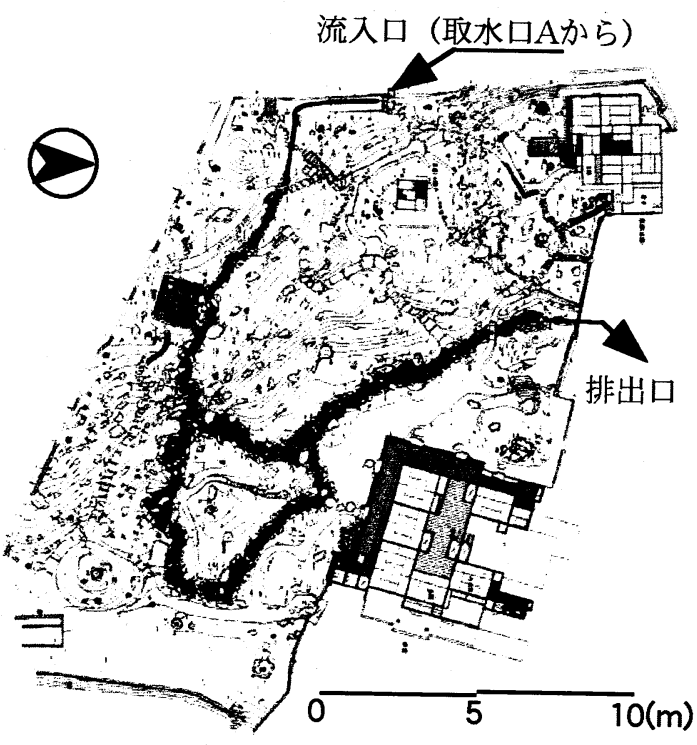

図-12 旧竹林院平面図

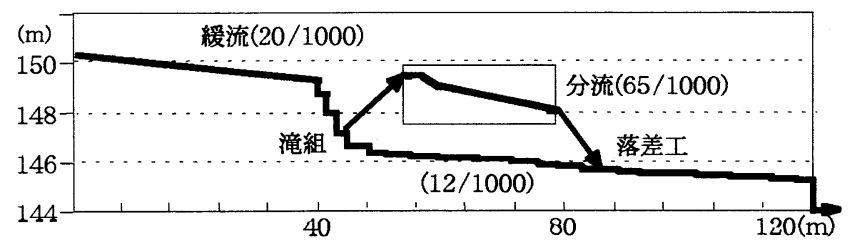

図-13，旧竹林院遣水縦断図
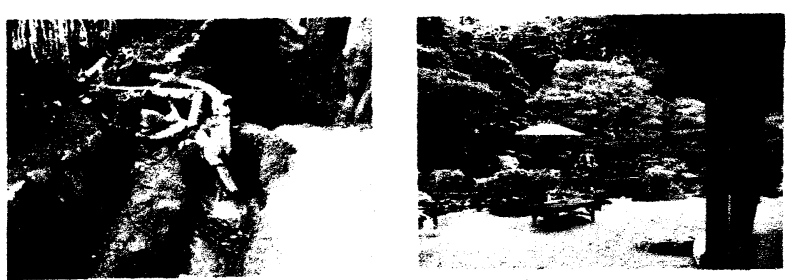

写真-7 竹林院サイフォン 写真-8 竹林院風景

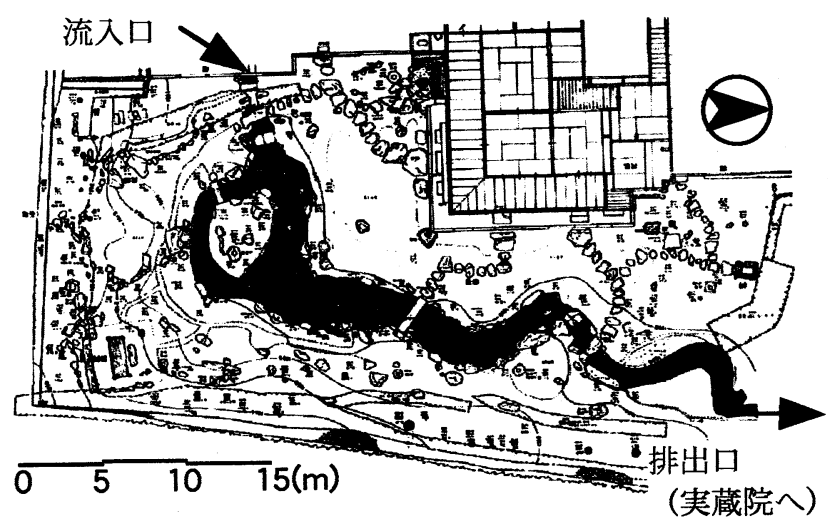

図-14 律院平面図

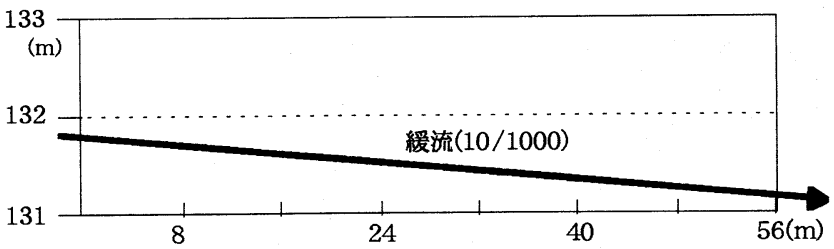

図-15 律院遣水縦断図 


\section{5.コミュニティの中での水路}

(1)管理・運営について

坂本には里坊以外にも町家・社家・農家といった居住形 態が存在し，この中でも里坊は他より高所に存在し，水利 用に関して優位であったことより里坊は水路網の取水管 理・運営に特別な役割を果たしていたと考えられる. 一方, 下流の町家・社家等には現存する明確な水路網は見られな かったため, 町全体としてのシステムは不明である.

水路のように上流から下流へ複数の利用者のあるものの 管理・運営は難しく, 律院・実蔵坊・寿量院・薬樹院とい ったように同一の水を利用する連なった庭園が存在するこ とは大変驚きである. おそらく里坊という比䫓山延暦寺と いう同一の信仰対象があったために可能となった仕組みで あると思われる.

現在も水路網は住民の管理に任されており，水路・遣水 の清掃，補修は住人の手によって行われている.

\section{(2)水路の変化}

長い歴史の中，幾つかの里坊庭園は改修工事，水位の低 下，管理の難しさなどの理由から流れを一時，または恒久 的に止めたりする事がある. これに伴い水路が変化したと いう事実がある．前出の図-2 以下に示した律院・実蔵 坊・寿量院は連続した水路を持っていたが，現況ではこれ 之異なった状態になっている. 一時的に実蔵坊の庭園が水 を止めたため, 背後に新たに水路を開削し, 寿量院はそこ から水を取り入れる様になった.

これは，図-3に示した水量調節段階が，2次から 3 次 に変化したことを意味する. そして，再び実蔵坊も水を流 す時に新たに開削した水路から水を引き，元に戻すという 形態をとった. つまり, 全体として, 管理がより簡単で, 安定した方向に水路は発展したと言える.

このような事実を踏まえると, 坂本での複雑な水路網は 水利用者の管理運営の容易さ, 安定化と言う方向に進んだ と推測される.

\section{6.まとめ}

\section{(1)結論}

今回の調查・分析により坂本の水路網の持つ以下のよう な特性が判明した.

(1)水路網に水量を段階的に調節する構造が存在する. この 段階的な調節により水路網全体は階層構造で説明でき，階 層構造の中, 特に余水吐け口が水量調整に重要な役割を果 たしている.

(2)ほぼ一様な区域の中に，水路網の特色を生かし，わずか な地形の違いを利用し，手を加えることで様々な水景が創 り出されている.

(3)坂本における水路網は自然河川・水路・庭園内の遣水之 なるにつれて, 自然の水を安定化させ，人間に近づけると いう意図がみられる.

(4)水路網ははじめから計画されてこのような形式を取った のではなく，規模が小さく工事が比較的しやすいため，よ り安定する力向に分岐が進み，現在のような形態となった と思われる.

\section{(2) 今後の課題}

坂本の水路網の形成過程と都市形成の過程には不明なと ころがあり, 今後の課題として挙げられる.

また，本研究で得られた水路網を用いた親水空間の構造 分析から，これからの親水計画をどのように行えばいいか， また実際の都市計画にどのように反映できるか，それによ る都市機能・交通・土地利用・コミュニティ・住民参加と いった問題点の研究が今後の課題として挙げられる.

\section{参考文献}

1）山田・中村他：「疏水の遣水的利用に関する研究」，環 境システム研究, Vol27, pp.255-265, 1999

2）大津市教育委員会編 :「坂本町並夕調查報告書」，1980

3）同上編：「坂本里坊庭園調查報告書」，1989

都市空間における遣水型水路網に関する研究

・河端 邦彦・山田圭二郎・中村 良夫 現在の親水空間の考え方は様々な施設を見ても人間が水に近づいていくという設計思想である. 本研究では日本人 が古くから持つ人と水との関係に着目し, 古代都市である坂本の水路網の構造を分析・考察した結果, 日本には 「自然」と「人」との間の取り方というものが存在し，自然を人間に近づける思想があったと考えら得られる.こ れらにより，局所的な親水空間の創造にとどまらず都市的な広域空間に親水空間を作る上での新たな視点，方法論 が与えられたと思う.

A Study on the Network of Landscaped Channels in Town

By Kunihiko KAWABATA, Keijiro YAMADA, Yoshio NAKAMURA

We understand that the amenity area of water is near the river or the lake. But Japanese have interesting idea about water. In this study, I focused on the water-network. Sakamoto in Siga has network of channels. This is an example that we can find the relation between nature and human. In this idea, we enjoy water not near nature but near human area. This idea have many application. We can propose new water front conception in the town. 